\title{
ZNISZCZENIA WOJENNE JAKO CZYNNIK DETERMINUJACY KRAJOBRAZ MIEJSKI NA PRZYKŁADZIE OŚRODKÓW POLSKI PÓŁNOCNO-WSCHODNIEJ I CO Z TEGO WYNIKA
}

\begin{abstract}
Streszczenie. Wojny zawsze miały znaczący wpływ na kształtowanie oblicza miast. Objawiało się to poprzez ewolucję systemów obwarowań, ale też przemianami zabudowy miejskiej i przedmiejskiej. W oczywisty sposób na dzieje ośrodków urbanistycznych miały wpływ zniszczenia wojenne, które prowadziły do kryzysu, niekiedy zaniku ośrodka miejskiego. Czasem były jednak impulsem do uzależnionej od wielu czynników, powolnej lub szybkiej, planowej lub chaotycznej odbudowy. Usuwanie zniszczeń polegało na dążeniu do przywrócenia stanu sprzed działań wojennych, ale zazwyczaj bywało też pretekstem do reform i korekt planistycznych, które prowadziły do dekonstrukcji i zatarcia pierwotnego układu. Niekiedy odbudowy nie podejmowano lub ograniczano tylko do wybranych budowli lub fragmentu, a funkcje centrum przejmowały przedmieścia. Specyfika wspomnianych zjawisk miała (i ma nada!!) pozytywny lub negatywny wpływ nie tylko na percepcję tych ośrodków, ale też na ich dalszy rozwój. Wspomniane wyżej zjawiska bardzo dobrze ilustrują miasta położone w Polsce północno-wschodniej (woj. warmińsko-mazurskim), czyli na terenie dawnych Prus Wschodnich. Miasta tej historycznej krainy zostały w przeważającej części dotknięte w XX wieku jedno-, a w części dwukrotnymi zniszczeniami wojennymi, a następnie bardzo niejednorodnymi formami odbudowy. Części miast wcale nie odbudowano lub ich historyczne centra zastąpiono dzielnicami bloków mieszkalnych. W dawnych śródmieściach powstały w konsekwencji takich działań niespójne i zdysharmonizowane zespoły zabudowy. Artykuł ma na celu charakterystykę tych zjawisk i próbę ich porównania. Stawia również pytanie, czy tradycyjny układ przestrzenny historycznego miasta jest potrzebny jego współczesnym mieszkańcom. Jako przykłady służą trzy miejscowości: Pasłęk, Pieniężno i Kisielice.
\end{abstract}

Słowa kluczowe: wojna, zniszczenia, architektura, krajobraz miejski, północno-wschodnia Polska, Prusy 
Si vis pacem, para bellum (Jeśli chcesz pokoju, szykuj się do wojny) - głosi porzekadło przypisywane rzymskiemu historykowi Wegecjuszowi. Warto zapytać, czy istnieje maksyma odwrotna. Bo jak szykować się, by odzyskać pokój po wojnie? Albo po prostu - jak przywrócić to, co wojna zniszczyła albo znaleźć nowe rozwiązania? Co ciekawe, brak chyba mądrych, łacińskich powiedzeń odnoszących się do tego tematu. Może i dziś nie zawsze potrafimy sprostać temu zadaniu.

Kataklizmy wojenne miały zawsze istotny wpływ na oblicze krain i miast. Przynosiły destrukcję, ale stwarzały jednocześnie szansę na zmiany wprowadzone po wojennej burzy. W miastach, bo one nas tu będą szczególnie interesować, objawiało się to dwojako - szykowaniem się na wojnę albo usuwaniem jej skutków. Oba zjawiska bywają w krajobrazie miejskim czytelne. Pierwsze z nich przejawiało się np. stałą ewolucją systemów obwarowań, ale też przemianami zabudowy śródmiejskiej - choćby likwidacją łatwopalnych drewnianych więźb domostw na rzecz płaskich dachów (np. w twierdzy Głogów) czy lokalizowaniem w strefach śródmiejskich różnorakich budowli służących wojskowemu garnizonowi (np. Olsztyn). Surowe przepisy dotyczyły jeszcze bardziej terenów przedmiejskich, w tym dopuszczanej na nich zabudowy. Wspomnieć można tzw. rewersy demolacyjne w miastach - twierdzach oznaczające przedkładanie bezpieczeństwa fortecy nad możliwościami rozwoju lub nakaz wznoszenia na przedpolach tylko obiektów nietrwałych. Dopiero po zburzeniu bastionowych obwarowań wiele miast otrzymało szansę na dalszy, nieskrępowany militarnymi zakazami rozwój.

Ale jest i druga strona medalu - to usuwanie zniszczeń i odbudowa realizowane sprawnie albo działania z różnych powodów odrzucone lub poniechane. Dysponujemy sporym zestawem przykładów zdobytych i zniszczonych miast - ośrodków odbudowywanych szybko i skrzętnie, ale też i tych, które nie podniosły się z destrukcji albo nigdy już nie odzyskały dawnej roli. Dlatego można stwierdzić, że „od zawsze” na dzieje ludzkich osiedli miały wpływ zniszczenia wojenne, które prowadziły nieuchronnie do kryzysu, stagnacji, upadku, niekiedy zaniku struktury miejskiej. Oczywiście zależało to od ich charakteru i skali - zastosowanych metod destrukcji i konsekwencji w ich wdrażaniu. Świetnie ukazują to miasta antyczne, dziś zazwyczaj tylko relikty ruin niegdysiejszych metropolii ulokowane obecnie w wiejskim krajobrazie. Można tu też przywołać nieudane, krótkotrwałe i potem „zaginione” lokacje średniowieczne 
(np. Nieszawa czy Szamotuły), choć one niekoniecznie przepadły w wyniku działań wojennych. Ale ukazują te zjawiska również miasta dwudziestowieczne zniszczone w trakcie dwóch wojen światowych. W niniejszym artykule bardziej będą nas interesować te poddawane przemianom po $1945 \mathrm{r}$.

Polska jest szczególnym krajem pod względem istnienia na jej terenie miast nieodbudowanych, niedokończonych, „znikłych”, zredukowanych. Tak się składa, że 76 lat po drugiej wojnie światowej istnieją w granicach naszego państwa miasta/ślady miast z wprawdzie usuniętymi ruinami, ale odbudowane fragmentarycznie - niekompletnie, niestanowiące do dziś spójnych organizmów pod względem przestrzennym i funkcjonalnym. Co ciekawe, wciąż funkcjonują, co sprzyja rozważaniom nad istotą pojęcia „miasto” albo „ośrodek miejski”. Wskazują, że mogą istnieć i działać osiedla w zredukowanej, kalekiej formie. Jak je nazwać? A może tworzą osobną grupę miejscowości o zredukowanych/ utraconych ze wspomnianych powodów cechach miejskich, ale też z racji historyczno-urbanistycznych zawierają wciąż potencjał umożliwiający przywrócenie takiego statusu prawdziwej, tradycyjnej miejskości? Rodzi to oczywiście kolejne pytania.

Zniszczenia miast były często impulsem do odbudowy - uzależnionej wprawdzie od wielu czynników, zwykle powolnej, ale jednak wywołanej praktycznymi, funkcjonalnymi potrzebami. Usuwanie zniszczeń niemal nigdy nie polegało na dążeniu do przywrócenia stanu sprzed kataklizmu, ale bywało też pretekstem do korekt planistycznych, które prowadziły niekiedy do likwidacji lub zmiany pierwotnego układu ${ }^{1}$. Procesy te uwidoczniały się w obrazie przestrzennym, układzie kompozycyjnym i funkcjonalnym, jak również charakterze zabudowy, stając się istotnym, czasem najważniejszym elementem oblicza nowego miasta i jego na nowo tworzonej tożsamości. Specyfika wspomnianych zjawisk miała (ma nadal!) pozytywny lub negatywny wpływ nie tylko na percepcję tych ośrodków, ale też - przede wszystkim - na ich codzienną egzystencję. W Polsce powojennej z oczywistych względów kładło się nacisk na odbudowy polityczno-historycznych, ale też gospodarczo istotnych miast takich jak Warszawa, Poznań, Gdańsk czy Wrocław. Pewnie osobno trzeba traktować Olsztyn i może Opole. W szeregu innych, mniej ważnych, jak np. w Elblągu, Głogowie

\footnotetext{
${ }^{1}$ Pomijam tu oczywiście wątek odbudów o charakterze rekonstrukcji, przynajmniej w formie zewnętrznej odtwarzającej zniszczone zespoły zabudowy. Stosowano je przynajmniej od pierwszej wojny światowej (np. Ypres), ale szeroko ich użyto po drugiej wojnie (np. Stare Miasto w Warszawie).
} 
lub Kołobrzegu, nie podjęto decyzji o szybkiej odbudowie śródmieść, tylko zaczęto ją realizować dopiero w końcówce PRL ${ }^{2}$. Czasem - jak w nadodrzańskim, granicznym Kostrzynie - nie było takich planów. Jeszcze niżej plasuje się grupa regionalnych ośrodków o znikomym znaczeniu - z „Polski powiatowej”.

Mimo ustrojowych przemian zazwyczaj eksponowane są w literaturze efekty udanie odbudowanych miast, odtworzonych - odzyskanych historycznych śródmieść. Czasem to jednak tylko echa propagandy czasów PRL, które skutecznie weryfikują współczesne badania, wskazując, że zburzone miasta powstały na nowo w zgrzebnej postaci, takiej, która wówczas była możliwa w skali i możliwościach straszliwie zniszczonego kraju. Istnieje jednocześnie odrębny wątek, mniej przyjemny, choć realistyczny, bo odczuwalny do dziś. Wątek miast, których odbudowy nie podjęto lub w pewnym momencie odpowiednie plany zatrzymano, bo nie były potrzebne. W latach sześćdziesiątych XX w. daje się zaobserwować charakterystyczne zjawisko - wyraźny brak potrzeby odbudowy śródmieść sporej części małych miast na ziemiach północnych i zachodnich. Wynikało to zapewne z ograniczonych możliwości ekonomicznych i uwarunkowań politycznych. Być może wynikało też z ideologii i utraty wiary w funkcjonowanie przestrzeni miejskiej wedle tradycjonalistycznych rozwiązań.

Przedmiotem rozważań w niniejszym artykule jest obecne województwo warmińsko-mazurskie, wchodzące w skład tzw. Ziem Odzyskanych. Nie wiadomo, czy po 1945 r. nie zakładano teoretycznie konieczności przywrócenia miejskiego charakteru i rangi zniszczonych miejscowości na terenach uzyskanych przez Polskę na mocy traktatów jałtańskich. Rzeczywistość wyglądała wszak inaczej. W obrębie polskiej części byłych Prus Wschodnich było to problematyczne - kompletnej przemianie uległa tu funkcjonalna struktura tej krainy, podzielonej teraz między dwa państwa. Przestała istnieć dotychczasowa logika szlaków komunikacyjnych, a linie kolejowe stopniowo rozbierano. Następował oczywisty upadek miast - zniszczonych i wyludnionych. Dlatego można założyć, że wspomniane w tytule zjawiska bardzo dobrze ilustrują ośrodki położone w Polsce północno-wschodniej (w woj. warmińsko-mazurskim) i obwodzie kaliningradzkim, w obrębie wtedy już podzielonych, dawnych Prus Wschodnich ${ }^{3}$.

${ }^{2}$ Kompletnie pomijam tu wątek „nowych-starych miast”, wymagający nowego, krytycznego omówienia. To pasjonujący temat, ale nie tutaj się nim zajmę.

3 Wątku dotyczącego obwodu kaliningradzkiego nie będę tu rozwijał. Trzeba stwierdzić, że tam nie podjęto odbudowy zniszczonych miast, a nawet zdecydowano o ich likwidacji. 
Miasta tej historycznej krainy zostały w przeważającej części dotknięte w XX w. jednokrotnymi, a w części dwukrotnymi zniszczeniami wojennymi, a następnie bardzo niejednorodnymi formami odbudowy. Niniejsze opracowanie zawiera charakterystykę tych zjawisk i stanowi próbę ich porównania, także w szerszym kontekście. Omawiane ośrodki zostały dość dotkliwie doświadczone dwudziestowiecznymi zniszczeniami wojennymi, rozbiórkami i niespójną, niekiedy niedokończoną odbudową ${ }^{4}$.

W znaczącym stopniu losy miast i miasteczek regionu obejmującego dawne Prusy Wschodnie ilustrują poświęcone im publikacje. Zagadnienie dwudziestowiecznych zniszczeń dawnej prowincji wschodniopruskiej, dziś województwa warmińsko-mazurskiego i obwodu kaliningradzkiego, było szeroko omawiane. Pomijam tu niezwykle bogatą literaturę odnoszącą się do odbudowy z lat 1914$1928^{5}$. Straty pierwszowojenne i proces ich likwidacji zostały najpełniej przedstawione w pracy Jana Salma ${ }^{6}$.

Z jednej strony zniszczenia kolejnej, drugiej wojny światowej były starannie klasyfikowane, a kolosalne straty w zabudowie, do jakich doszło w trakcie walk 1945 r. i okresu późniejszego, zestawia m.in. pierwsza powojenna monografia regionu? ${ }^{7}$ Z pewnością warto jako punkt wyjścia do bardziej szczegółowych analiz przyjąć zestawienie dokonane przez Tadeusza Domagałę. Z drugiej strony brak jest oceny ,jakościowej” - jakie obiekty i zespoły zostały zniszczone, co to oznaczało dla ośrodków miejskich, w których były ulokowane. Zazwyczaj brak też danych, czy destrukcja nastąpiła w trakcie działań wojennych, czy była wynikiem degradacji następującej w kolejnych, powojennych latach. Symboliczne przykłady - np. Elbląg, Lidzbark Warmiński, Legnica czy Nysa - zdają się świadczyć, że efektem wojny oprócz zniszczeń związanych

${ }^{4}$ J. SALM, Miasta po trzykroć odbudowywane. Koleje losu historycznych ośrodków miejskich Polski Pótnocno-Wschodniej w 20. wieku, [w:] Tożsamość miasta odbudowanego. Autentyzm - integralność - kontynuacja. Materiaty międzynarodowej konferencji naukowej, Gdańsk, 10-11 maja 2001 roku, red. M. CieląTKOWSKA, Gdańsk 2001, s. 107-112, 239-244.

5 Vide: Der Wiederaufbau Ostpreußens. Eine kulturelle, verwaltungstechnische und baukünstlerische Leistung, hrsg. von E. GÖTTGEN, Königsberg 1928.

${ }^{6} \mathrm{~J}$. SALM, Odbudowa miast wschodniopruskich po I wojnie światowej. Zagadnienia architektoniczno-urbanistyczne, Olsztyn 2006.

7 Warmia i Mazury, t. 2, red. S. Zajchowska, M. KięCZewska-Zaleska, Poznań 1953, s. 268.

8 T. Domagata, Miasta wschodniopruskie w okresie zimowej ofensywy Armii Czerwonej w 1945 roku, [w:] Odbudowa miast historycznych. Dokonania przesztości. Potrzeby i możliwości wspótczesne. Wyzwania przysztości, red. M. LuBOcKA-Hoffmann, Elbląg 1998, s. 40-54. 
z działaniami zbrojnymi było także doprowadzenie do trwającej kilka dekad stopniowej destrukcji śródmieść. Obszary te traciły na znaczeniu w wyniku utraty funkcjonalnej sprawności. Nieopracowane dostatecznie i niejednolite źródła mówią zazwyczaj o rozbieraniu ruin, ale i jeszcze nadających się do odbudowy zespołów domostw oraz wywózce pozyskanego materiału budowlanego. Być może da się kiedyś uściślić i zweryfikować te opinie. Zapewne głównie uwarunkowania polityczne i realia gospodarcze lat powojennych spowodowały, że sporej grupy zwłaszcza małych miast nie odbudowano w obrębie zniszczonych centrów lub prowadzono ten proces chaotycznie, bez jasno określonej koncepcji. Czasem, w latach środkowego lub późnego PRL, podejmowano jednocześnie próby kompleksowego podejścia do odbudowy i opierano ją na przygotowanej przez specjalistów strategii ${ }^{9}$. Jednocześnie, poczynając od początku lat sześćdziesiątych XX w., zaczęto wprowadzać w obręb historycznych, zburzonych, ale uwolnionych od ruin śródmieść stypizowaną zabudowę blokową. O konsekwencjach ich funkcjonowania, ale też ogólnej kondycji i oblicza przestrzennego rzadko się wspomina, choć mamy na interesującym nas obszarze przykłady niekiedy bardzo sugestywne, jak np. Pasłę ${ }^{10}$. Wiele innych historycznych śródmieść regionu, po usunięciu ruin, potraktowano podobnie. Tyle że nie powstały na ich temat stosowne analizy, które ukazywałyby zaistniałe przemiany, w tym zarówno ich pozytywne skutki, jak i skalę błędów i zaniechań.

Sygnalizowane zjawiska - nieuchronne zniszczenie historycznego ośrodka, wyburzenie ruin w ramach akcji porządkowych, przebiegająca w kilku fazach fragmentaryczna odbudowa - były omawiane w szeregu publikacji. Ważnym zaczątkiem prac nad koncepcjami odbudowy miasteczek i miast regionu były działania pracowników Zakładu Urbanistyki Wydziału Architektury Politechniki Warszawskiej. W ramach tych prac dokonywano m.in. inwentaryzacji

9 Mam tu na myśli np. Kazimierz nad Wisłą czy Szydłów. Odnośnie do interesującego nas obszaru uwzględnić można trzy planowe przedsięwzięcia: odbudowę starego miasta w Olsztynie, nie do końca klarowne przedsięwzięcie dotyczące Fromborka (akcja kopernikańska) i oczywiście wspomniany już Elbląg - realizację łączącą schyłek PRL z nowymi czasami. Wszystkie wymagają dokładnej analizy, której tutaj się nie podejmę.

10 J. SAlm, Problematyka powojennej odbudowy i badań zespotu Starego Miasta w Pastęku, „Archeologia Historica Polona” 1996, t. 3: Materiaty z II międzynarodowej sesji naukowej Uniwersyteckiego Centrum Archeologii Średniowiecza i Nowożytności. Eódź 18-19 października 1993 roku, Toruń 1996, s. 301-314. 
urbanistycznych i opracowywano propozycje planów miejscowych dla tych ośrodków ${ }^{11}$. W fachowej literaturze problem odbudowy miasteczek Warmii i Mazur praktycznie do lat osiemdziesiątych XX w. nie był traktowany jako odrębne zjawisko ani przedstawiany w osobnych publikacjach. Otwiera ten przegląd do pewnego stopnia pionierski artykuł K. Pawłowskiego, świadczący o wczesnym zainteresowaniu się przez niektórych badaczy problematyką kształtowania przestrzeni i zabudowy historycznych śródmieść ówczesnego województwa olsztyńskiego ${ }^{12}$. Tematyka ta powracała później dość sporadycznie w innych publikacjach ${ }^{13}$. Zagadnienie odbudowy miast Warmii i Mazur nie zostało dostatecznie omówione w monumentalnej, niestety ograniczonej do jednego tomu publikacji schyłkowego PRL. Miała ona w założeniu zaprezentować zabytki architektury i urbanistyki z terenu Polski i związane z nimi kwestie konserwatorskie ${ }^{14}$. Mierne efekty odbudowy albo realizacje nieudane nie były w niej dokładniej analizowane lub poświęcono im tylko zdawkowe wzmianki ${ }^{15}$. Sytuacja zmieniła się po transformacji ustrojowej. Niewątpliwie ważną pozycją jest oparta na bogatym materiale archiwalnym praca Marii Lubockiej-Hoffmann, konserwatorki zabytków pełniącej wówczas funkcję Wojewódzkiego Konserwatora Zabytków, związanej szczególnie z wyjątkowym procesem przywrócenia do życia Starego Miasta w Elblągu ${ }^{16}$. Autorka charakteryzuje zniszczenia i powojenne procesy zachodzące w ośrodkach miejskich Polski północnej i zachodniej, ale w bardzo ograniczonym stopniu analizuje i przedstawia efekty odbudowy poszczególnych ośrodków. Odnosi się to m.in. do zmian zaistniałych w stosunku do stanu sprzed zniszczeń struktury zabudowy i rozplanowania

${ }^{11}$ H. AdAMCZEWSKA-WeJCHERT, K. WEJCHERT, Mate miasta, problemy urbanistyczne stale aktualne, Warszawa 1986, s. 149-180.

${ }_{12}$ K. PAWŁOWSKI, Problemy nowej zabudowy w zabytkowych zespotach urbanistycznych Polski pótnocnej, [w:] Zagadnienia ksztaltowania nowej zabudowy mieszkaniowej i ustugowej w uktadach zabytkowych matych miast. Materiaty $z$ konferencji TUP $w$ Olsztynie, red. H. ADAMCZEWSKA-WeJCHERT, Z. JACZEWSKI, Olsztyn 1971, s. 121-128.

13 J. SALM, W poszukiwaniu zapomnianej tradycji. Nowa architektura w historycznych ośrodkach Polski Pótnocno-Wschodniej, [w:] Architektura wspótczesna w środowisku historycznym, red. R. MiкIELEWICZ, Pasłęk 1995, s. 46-59.

${ }_{14}$ Zabytki urbanistyki i architektury w Polsce. Odbudowa i konserwacja, red. W. ZIN, t. 1: Miasta historyczne, red. W. KALINOWSKI, Warszawa 1986.

15 Ibidem, s. 56-57.

16 M. Lubocka-Hoffmann, Miasta historyczne Zachodniej i Pótnocnej Polski. Zniszczenia i programy odbudowy, Bydgoszcz 2004. 
omawianych ośrodków miejskich. Nie ma w wzmiankowanej pracy odpowiedniej refleksji na temat uzyskanych efektów, przynajmniej w odniesieniu do problematyki konserwatorskiej. Warto zauważyć, że publikacja dotycząca dużej grupy historycznych układów urbanistycznych zaopatrzona została w niezwykle skromny materiał kartograficzny ${ }^{17}$. Nieco inaczej na oblicze miast Polski północno-wschodniej próbował spojrzeć J. Salm, odnosząc się m.in. do zagadnienia integralności tych często niejednolitych układów przestrzennych ${ }^{18}$.

Próbę ogólnej charakterystyki przemian i stanu zachowania historycznych układów urbanistycznych z terenu woj. warmińsko-mazurskiego starał się przedstawić Jacek Wysocki w zbiorowej pracy dotyczącej dziedzictwa kulturowego regionu ${ }^{19}$. Wspomnieć też wypada o problematyce rewaloryzacji (używając aktualnej terminologii - rewitalizacji) ciężko doświadczonych przez wojnę małych miast, w tym o zagadnieniu ich badań, zwłaszcza archeologicznych ${ }^{20}$. Pogłębioną charakterystykę niewielkiej grupy ośrodków miejskich dawnych Prus Zachodnich (obecnie zachodnich obrzeży woj. warmińsko-mazurskiego) pod kątem stanu ich zachowania i potencjału odbudowy przedstawił Jerzy Domino $^{21}$. To być może najbardziej surowa diagnoza, zarówno pod względem charakterystyki zniszczeń, skomentowania efektów fragmentarycznej odbudowy i rysujących się perspektyw. Warto na koniec tego ogólnego przeglądu literatury przedmiotu wspomnieć o artykule Zbigniewa Czernika, stanowiącym próbę kompleksowego spojrzenia na powojenną odbudowę miast regionu $^{22}$.

Reasumując, w praktycznie żadnej polskiej publikacji powojennej nie podjęto rzeczowej dyskusji o konsekwencjach funkcjonalnych, jakie przyniosło

17 W przywołanej książce znajduje się tylko jeden (!) plan ukazujący stan zabudowy centrum Sulechowa w 1957 r. Trudno ocenić, dlaczego właśnie on został wybrany do ilustracji znacznie bardziej złożonego problemu, Cf: : ibidem, s. 26.

18 J. SALM, Miasta po trzykroć odbudowywane..., s. 107-112.

19 Dziedzictwo kulturowe Warmii-Mazur-Powiśla. Stan zachowania, potencjaty i problemy, red. J. Wysocki, Olsztyn 2006, s. 86-107.

20 Badania archeologiczne starych miast Warmii i Mazur a problemy ich rewaloryzacji. Materiaty z konferencji, Wykno 12-14 XI 1997, red. J. Wysocki, J. MichaLSKI, Nidzica 1998.

21 J. Domino, Biskupiec, Dąbrówno, Kisielice, Mitomtyn, Susz, Zalewo. Szanse - brak szans, „Kurier Konserwatorski” 2010, nr 9, s. 22-28.

22 Z. CZERnIK, Architektura w obliczu wojennych zniszczeń. Odbudowa miast wschodniopruskich w PRL, [w:] Między formą a ideologia. Architektura XX wieku w Polsce, red. E. PERLIŃsKA-KOBIERZYCKA, Warszawa 2012, s. 147-164. 
zniszczenie, a potem rozebranie sporej części zabudowy śródmieść zwłaszcza małych i średnich miast słabego gospodarczo, ale kulturowo atrakcyjnego regionu, jakim wciąż pozostaje Warmińsko-Mazurskie. Brak też całościowego opracowania, które precyzyjnie i krytycznie omawiałoby dotychczasowe procesy odbudowy lub rewitalizacji znajdujących się tu małych ośrodków miejskich.

Oprócz publikacji, których wybór został wyżej przedstawiony, ilustrację wspomnianych procesów stanowią jednak konkrety, czyli realizacje. Nie miejsce tu na ich szczegółową prezentację. Na jednym biegunie stoją wcielone w życie projekty, takie jak np. stare miasto w Olsztynie ${ }^{23}$. Są też realizacje dyskusyjne, takie jak np. blokowe osiedla staromiejskie wzniesione w Morągu, Lidzbarku Warmińskim czy Olsztynku. I one wymagają badań i oceny. Ale historyczne miasta regionu z ich zdeformowaną, zubożoną strukturą przestrzenną wciąż istnieją. Jednym z oczywistych celów odtworzenia albo uratowania ich indywidualnych, swoistych cech powinna być ochrona historycznych enklaw - zachowanych zespołów zabudowy sprzed 1945 r., niekoniecznie cennych architektonicznie, ale ważnych jako reprezentatywne zespoły ${ }^{24}$. Przykładem tego typu działań jest renowacja zespołu przymurnych domów w Dobrym Mieście na Warmii, ulokowanych wzdłuż wschodniego odcinka dawnych obwarowań (między basztą Bocianią i reliktami jej odpowiedniczki w północno-wschodnim narożu $)^{25}$.

Powyższe konstatacje nie zmieniają faktu, że na szczególne zainteresowanie zasługują jednak inne miasta tego regionu, ilustrujące efekt zaniechania i opuszczenia albo podjęcia działań niekoniecznie trafnych, bo nieudanych w zakresie przywrócenia spoistego układu przestrzennego ich śródmieść. Wyróżniają się spośród nich trzy ośrodki: górnopruski Pasłęk, warmińskie Pieniężno oraz Kisielice położone w dawnych Prusach Zachodnich. Wydaje się, że ilustrują one dobrze problematykę przestrzenną zdecydowanie większej grupy miast - istnienie we współczesnym urbanistycznym krajobrazie Polski miast niedokończonych/nieodtworzonych i zawierających w swym krajobrazie wyraźne ślady wojny.

23 A. RzempoeUCH, Architektura i urbanistyka Olsztyna 1353-1953, Olsztyn 2005, s. 2.

${ }_{24} \mathrm{~J}$. SALM, Idea Cittaslow a tożsamość miast województwa warmińsko-mazurskiego. Między Umbria a Warmiq i Mazurami, [w:] Alternatywne modele rozwoju miast. Sieć miast Cittaslow, red. E. STRZELECKA, Łódź 2017, s. 73-81.

${ }_{25}$ Ten wartościowy przykład nie został dotąd omówiony w jakiejkolwiek publikacji. 

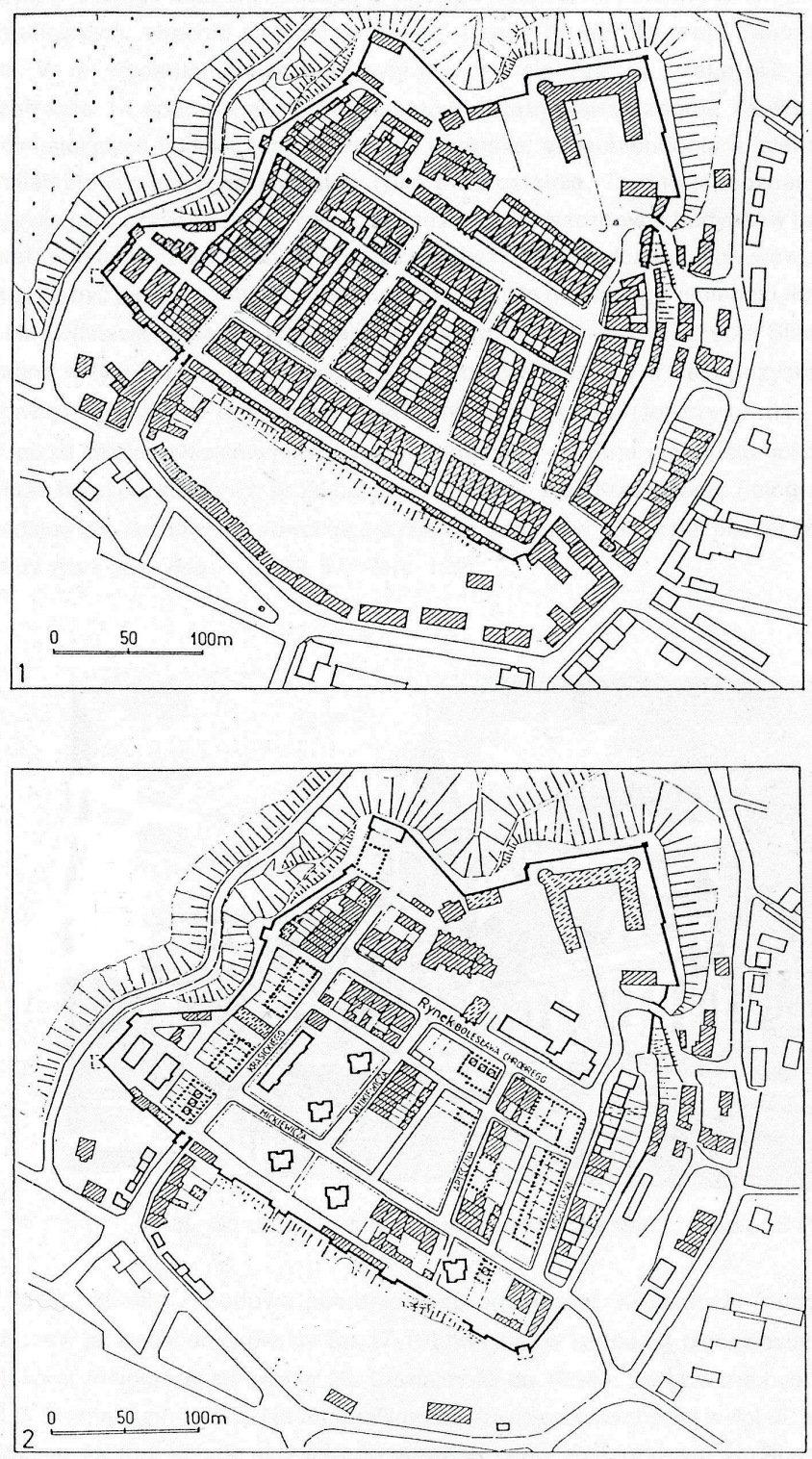

Ryc. 1 i 2. Pastęk, plan starego miasta przed 1945 r. i w 1995 r. (oprac. J. SALM)

Pasłęk to miasto o trzynastowiecznej genezie (lokacja 1297 r.) i nietypowym rozplanowaniu z ulicowym rynkiem i podziałem terytorium miejskiego na północną strefę administracyjno-sakralną i południową - mieszczańską. Stare Miasto uległo poważnej destrukcji - spaleniu, a potem stopniowej rozbiórce w latach 1945-1958. 
Z około 180 domów w obrębie murów przetrwało do dziś niespełna 40, do tego nie najbardziej cennych architektonicznie. Niejednolite i niekonsekwentne podejście do odbudowy doprowadziło do powstania niespójnego krajobrazu miejskiego, specyficznego konglomeratu zróżnicowanych struktur miejskich ${ }^{26}$.

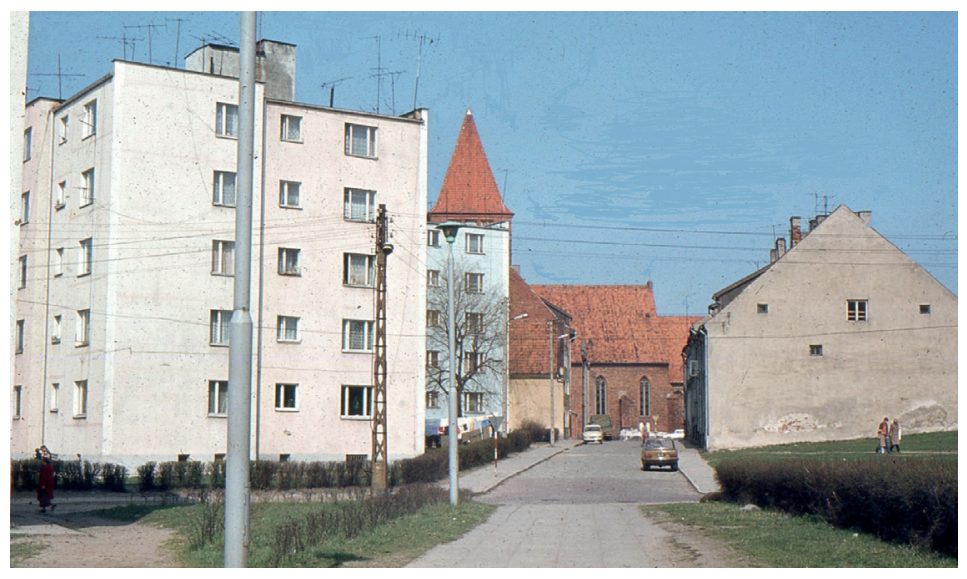

Ryc. 3. Pasłęk - ul. Sienkiewicza w 2021 r. (fot. Janusz Otręba)

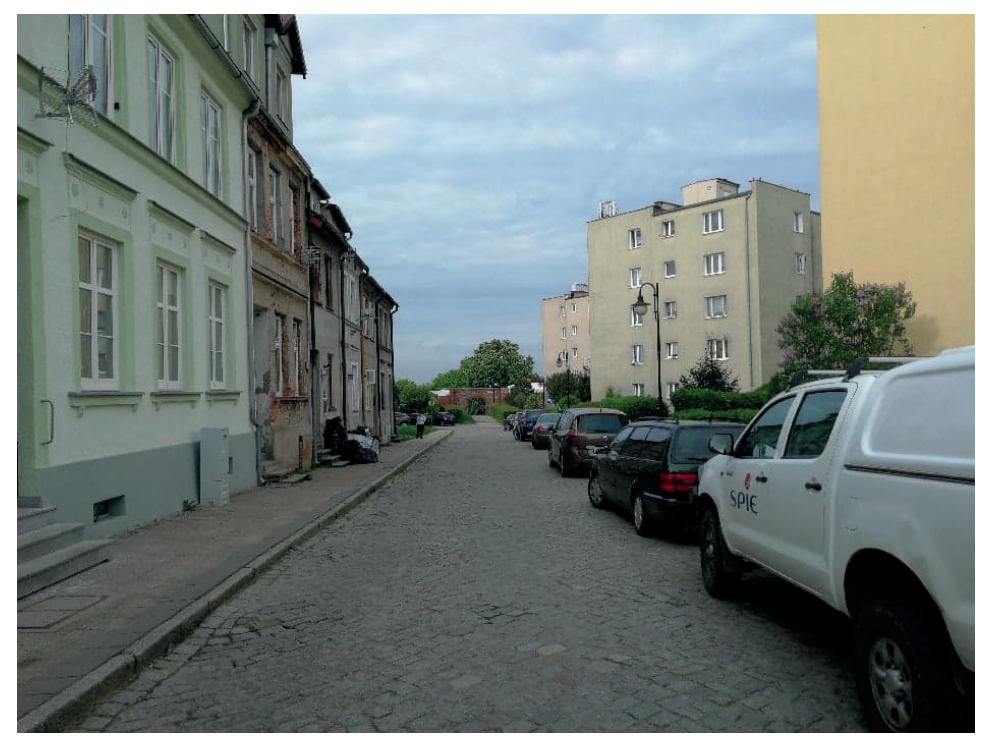

Ryc. 4. Pasłęk - ul. Sienkiewicza w 2021 r. (fot. Janusz Otręba)

${ }^{26}$ J. SALM, Problematyka powojennej odbudowy..., s. 301-314. 
Może właśnie tu, spośród miast zachowujących relikty dawnej struktury zabudowy, najbardziej uwidocznione są fazy przemian zaistniałych po 1945 r. na tle historycznej substancji. W śródmieściu podjęto odbudowę ratusza i zamku. Ocalały też kościół i niewielki zespół kamienic. W latach sześćdziesiątych XXw. wprowadzono na pusty teren starego miasta 5-kondygnacyjne bloki mieszkalne i pawilon handlowy. Później, już w latach siedemdziesiątych XX w., poczęto przywracać zabudowę pierzejową (ul. Tadeusza Kościuszki). Przyjęła ona postać jednorodzinnych domów z usługami i handlem w parterach i miała nawiązywać do historycznej, szczytowej zabudowy. Mimo mankamentów to jedna z pierwszych tego typu realizacji przeprowadzonych w warunkach PRL. Etap po $1989 \mathrm{r}$. ma jeszcze inny charakter. Inwestycje tego okresu opierały się na założeniach uchwalonego w 1993 r. Miejscowego Planu Zagospodarowania Przestrzennego i opracowanej w jego ramach nowej parcelacji terenów staromiejskich. W kolejnych latach na działkach zrealizowanych zostało ponad 20 domów - kamieniczek. Proces ten nie wiązał się z kompleksowymi badaniami archeologicznymi, co uznać trzeba za spore zaniechanie.

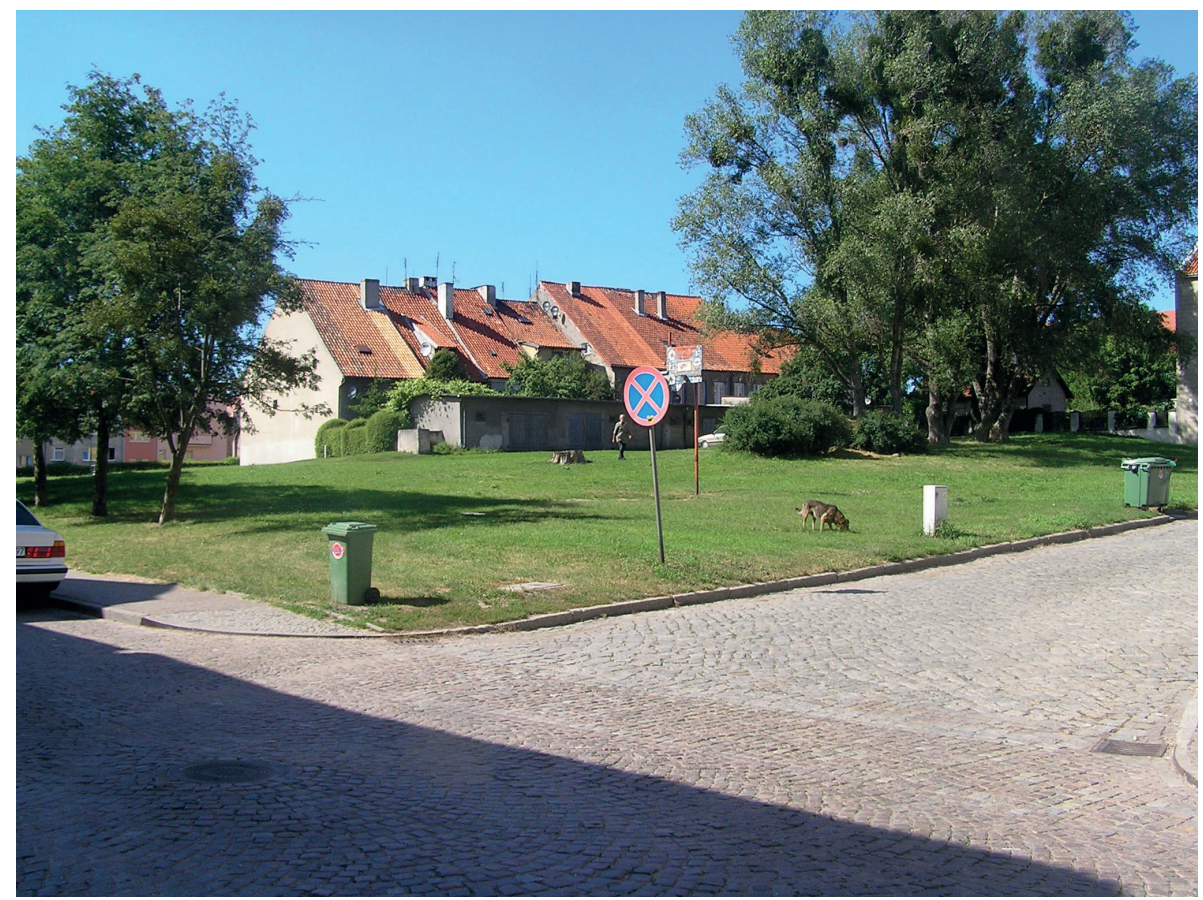

Ryc. 5. Pasłęk - skrzyżowanie ul. Aptecznej i ul. Adama Mickiewicza w 2010 r. (fot. Jan Salm) 
Po 2000 r. ruch inwestycyjny stopniowo słabł i część parcel pozostała do dziś niezabudowana. Pasłęk, a ściśle jego układ staromiejski oparty na średniowiecznym rozplanowaniu, stanowi dziś niespójny organizm, w którym występują obok siebie relikty historycznej zabudowy sprzed 1945 r. (w tym monumentalne obiekty: mury obronne, kościół parafialny, ratusz i zamek), puste tereny będące efektem zniszczeń i powojennych rozbiórek, dwie fazy zabudowy z czasów PRL - bloki i skromna zabudowa pierzejowa oraz zróżnicowane architektonicznie nowe kamieniczki z przełomu XX i XXI w. Nie ulega wątpliwości, że i tu 76 lat po kataklizmie wojennym proces odbudowy nie został w pełni ukończony. Jednocześnie pasłęckie stare miasto, pozostając wartościowym, choć kalekim zespołem zabytkowym, jest świetnym przykładem meandrów powojennej odbudowy.

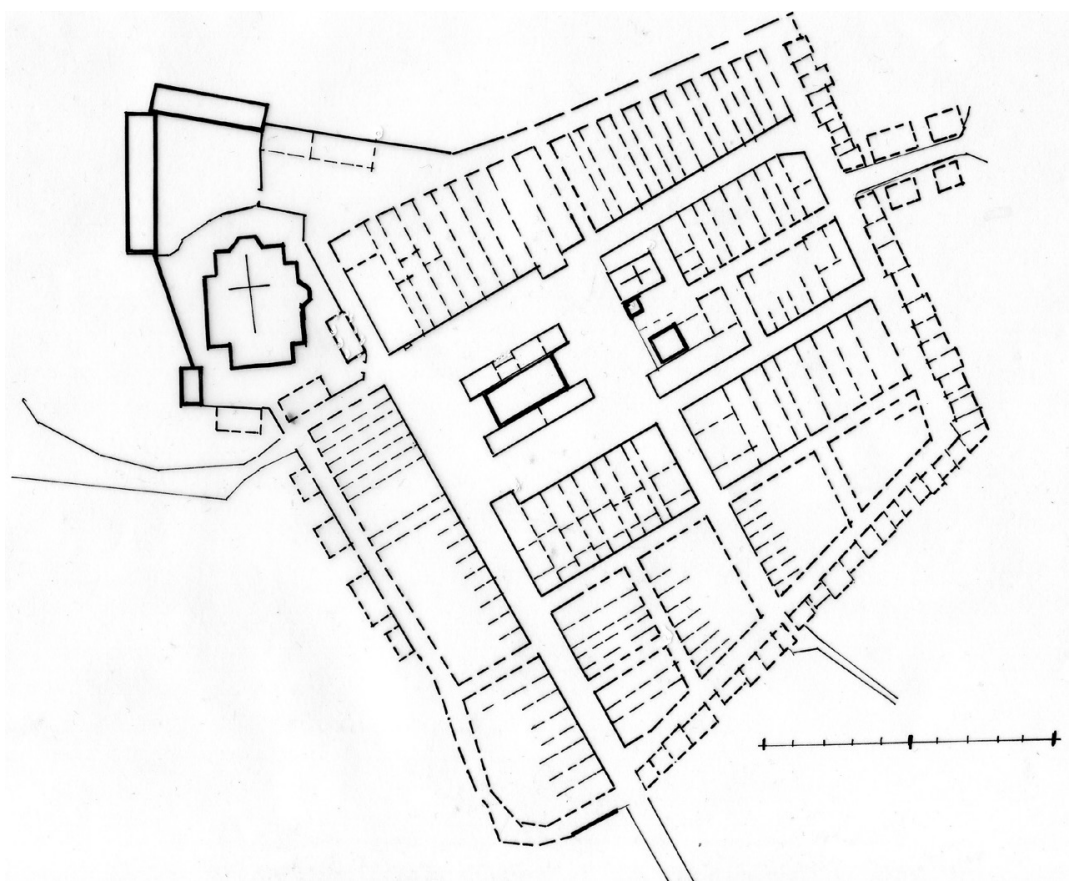

Ryc. 6. Pieniężno, plan starego miasta przed 1945 r. (oprac. J. SALM)

Pieniężno (lokacja ok. 1312 r.) stanowi w północno-wschodniej części Polski wymowny przykład atrofii historycznego układu miejskiego ${ }^{27}$. Jeden z najpiękniejszych, najbardziej wyrazistych zespołów urbanistycznych Warmii spłonął

${ }^{27}$ A. RzempoŁuch, Pieniężno, „Spotkania z Zabytkami” 1987, nr 4, s. 36-38. 
w styczniu 1945 r. i następnie nie doczekał się odbudowy. Zapewne stało się tak z racji marginalnej roli ośrodka - położenia przy praktycznie martwej granicznej rubieży z obwodem kaliningradzkim oraz znikomego znaczenia gospodarczego. Funkcje ulokowane dawniej w historycznym centrum przejęły przedmieścia.

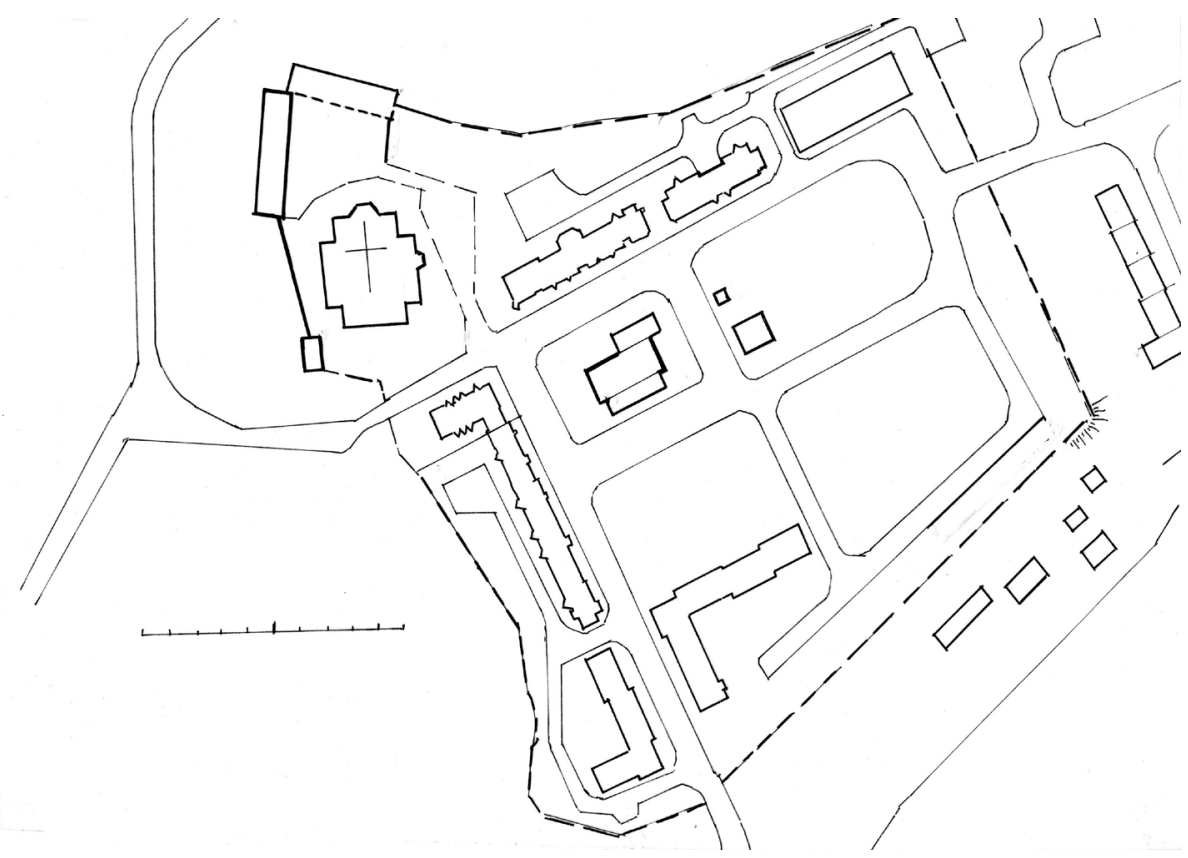

Ryc. 7. Pieniężno, plan starego miasta w 2020 r. (oprac. J. SALM)

Pieniężno nigdy nie było ludnym ośrodkiem - przed wojną liczyło ok. 4,4 tys. mieszkańców, w 1946 r. było ich zaledwie 640. Dziś zamieszkuje je niespełna 3 tys. osób. Centrum historyczne, ulokowane na płaskowyżu ponad malowniczą doliną rzeki Wałszy, utraciło w wyniku wojny praktycznie całą zabudowę oprócz obiektów monumentalnych. Przepadły m.in. jednolicie ukształtowane pierzeje rynku z charakterystycznymi podcieniowymi kamienicami w trzech narożnikach placu oraz zespół specyficznych domów tkackich o ujednoliconych fasadach. Nienadające się do zasiedlenia ruiny starego miasta w pierwszej dekadzie powojennej sukcesywnie rozbierano. Zachowały się jedynie dawny zamek kapitulny i rzymsko-katolicki kościół parafialny z wikarówką. Świątynię protestancką z pierwszej połowy XIX w. ulokowaną przy rynku, która przetrwała 
wojnę, rozebrano chyba ok. 1960 r., pozostawiając wolno stojącą dzwonnicę i dom parafialny. To jedyny przedwojenny budynek mieszkalny zachowany w obrębie starego miasta (!). Specyficzną inwestycją przeprowadzoną we wczesnych latach PRL (ok. 1960 r.) była budowa pawilonu handlowego pozbawionego jakichkolwiek walorów architektonicznych ani też wpływu na odzyskanie rangi przez teren staromiejski. Już w późnych latach osiemdziesiątych XX w. podjęto odbudowę ruin ratusza na dawnym placu rynkowym. Inwestycji tej do dzisiaj nie ukończono, choć powstała w stanie surowym ceglana bryła z charakterystyczną sygnaturką. W międzyczasie wzniesione też zostały nowa plebania i zespół trzech prefabrykowanych bloków w południowej części starego miasta. Jeszcze później (ok. 1995 r.) zrealizowano postmodernistyczną mieszkaniówkę przy północnej pierzei rynku i blok wielorodzinny w krótkiej pierzei zachodniej, wzdłuż ul. Orneckiej. Ich fronty zostały cofnięte względem historycznej linii zabudowy ${ }^{28}$.

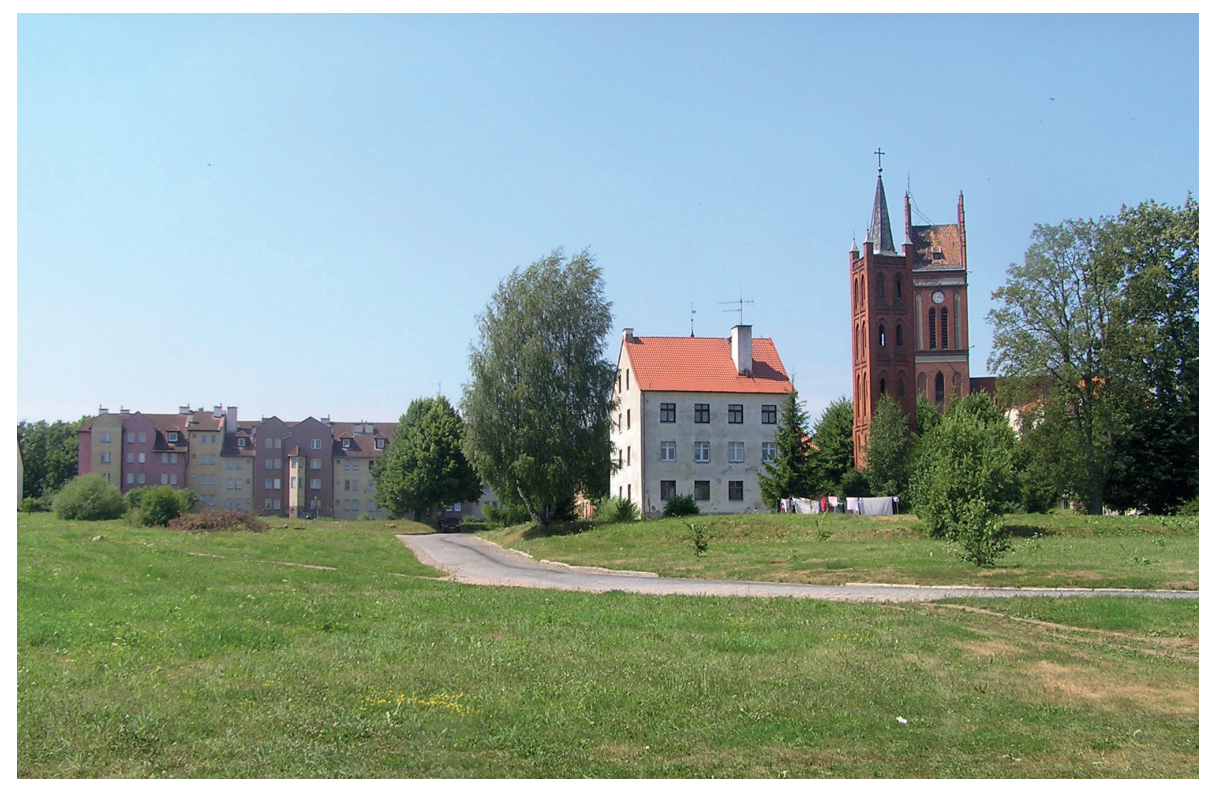

Ryc. 8. Pieniężno, historyczne centrum miasta - widok z 2020 r. (fot. Jan Salm)

Co charakterystyczne, zatarciu uległo w dużej części rozplanowanie miasta, w tym przebieg części ulic. Dawne stare miasto to dziś obszar o trudnej do zdefiniowania przestrzeni i utraconej czytelności pierwotnego rozplanowania. Duża

\footnotetext{
${ }^{28}$ J. SALM, W poszukiwaniu zapomnianej tradycji..., s. 55.
} 
jego część to tereny otwartej zieleni (łąki) funkcjonujące w miejscu wyburzonej historycznej zabudowy. Tylko na osi dawnego wschodniego wjazdu w obręb średniowiecznej lokacji usytuowano pomnik z figurą papieża Jana Pawła II z masztami flagowymi. Czy staremu miastu w Pieniężnie pisana jest rola swoistego memento, przypominającego o trwonieniu szans na przemyślaną odbudowę i oznaczającego zgodę na funkcjonowanie quasi-miejskich organizmów zdeprecjonowanych przestrzennie i funkcjonalnie? Pieniężno stanowi dla mnie nie tylko przykład zaniechania szansy ratowania historycznego miasteczka o sporych walorach zabytkowych i krajobrazowych. Jednocześnie to ewidentny dowód braku potrzeby na przywrócenie/odzyskanie „miejskości”. Ale też stworzenia (może po prostu przywrócenia) dostosowanego do ograniczonych, lokalnych potrzeb małego centrum. Co wydarzy się w Pieniężnie dalej, czas pokaże.

Można uznać, że w województwie warmińsko-mazurskim najbardziej sugestywnym przykładem zaniku starego centrum i utrzymania do dziś jego obszaru w stanie po usunięciu śladów destrukcji wojennej są Kisielice (lokacja 1331 r.; powiat Iława) ${ }^{29}$.

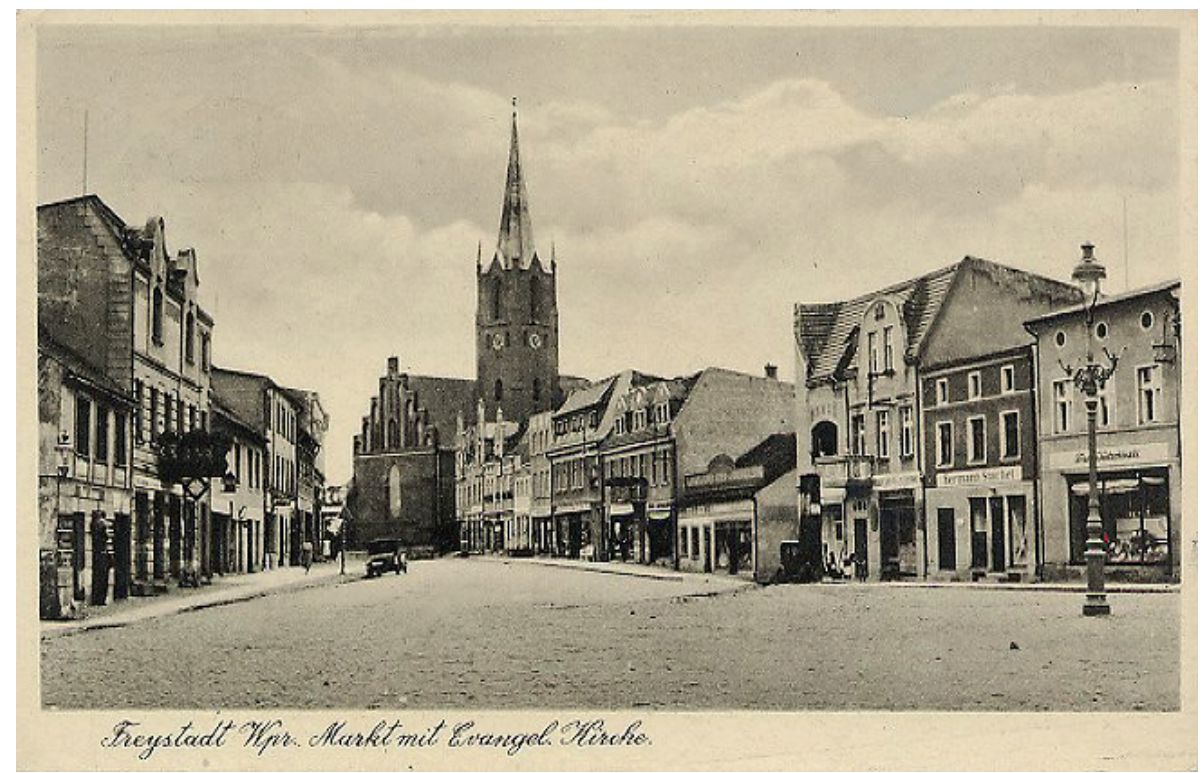

Ryc. 9. Kisielice, plac rynkowy przed 1945 r. - widok w kierunku południowym (źródło: Der Kreis Rosenberg in alten Ansichtskarten. Aus der Sammlung von Christa Mühleisen, http://aefl.de/rosenberg/Rosenberg/kreisrosenbergindex.htm, dostęp: 15 X 2020)

29 L. Czubiel, T. DomagaŁa, Zabytkowe ośrodki miejskie Warmii i Mazur, Olsztyn 1969, s. 163165; J. Domino, op. cit., s. 27. 
Miejscowość historycznie związana jest z PrusamiZachodnimi, to ośrodek szczególnie ciężko doświadczony przez wydarzenia wojenne (zniszczenie ponad 70 procent tkanki miejskiej) i późniejsze decyzje o odstąpieniu od odbudowy. Po 1945 r. nie zdecydowano się na podniesienie $\mathrm{z}$ ruin obszaru średniowiecznej lokacji wraz z charakterystycznym placem rynkowym, mającym postać wydłużonego trójkąta. Odbudowano jedynie spalony kościół i utrzymano komunikacyjne znaczenie dawnego centrum z przebiegającą przez nie trasą tranzytową Iława-Grudziądz. Ruiny zabudowy stopniowo rozebrano. Pewnie i tu zasadniczą rolę odegrał ograniczony potencjał miejscowości. Ale geneza tych decyzji pozostaje nieznana i wymaga badań. Podobnie jak w wypadku Pieniężna bardzo ciekawym tematem staje się wątek przeobrażeń funkcjonalnych, w tym pytanie - jak małe miasto (dziś nieco ponad 2 tys. mieszkańców) poradziło sobie z utratą historycznego centrum i na ile sprawnie dziś - ponad 70 lat po rezygnacji z odtworzenia dawnego centrum - funkcjonuje w oparciu o dzielnice przedmiejskie? Czy powstała w nich przestrzeń publiczna będąca ekwiwalentem lub substytutem dawnego placu rynkowego? Chyba nie. Być może ludność żyjąca w takim miasteczku, ale i w innych podobnie okaleczonych ośrodkach nie potrzebowała odtworzenia tego typu przestrzeni. To kolejny, frapujący wątek badań już nie urbanistycznych, ale socjologicznych.

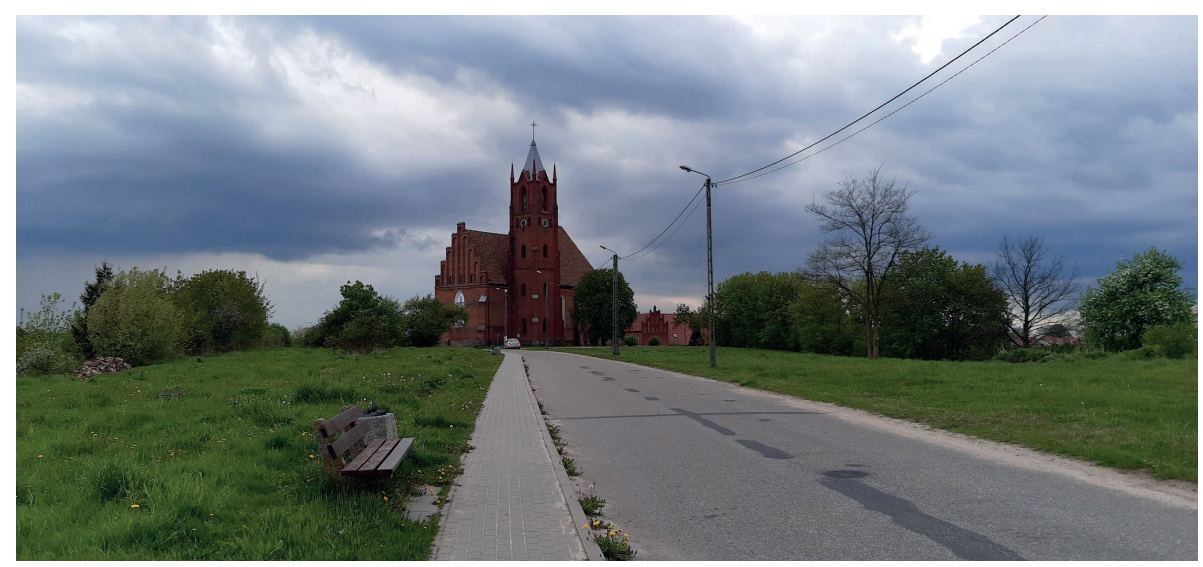

Ryc. 10. Kisielice, plac rynkowy - widok w kierunku południowym z 2021 r. (fot. Piotr Blinkiewicz)

Powyższe przykłady i związane z nimi pytania mają charakter szerszy. Zbliżonych pod względem problematyki „kalekich”, niekompletnych przestrzennie i funkcjonalnie miejscowości (niegdysiejszych miast) jest w województwie warmińsko-mazurskim więcej. Wystarczy spojrzeć choćby na Młynary, Braniewo, 
Miłakowo, Miłomłyn, Zalewo, Nidzicę, Dobre Miasto, Sępopol i jeszcze kilka innych. Powraca wątek zniszczeń i podnoszenia się z ruin. Niemal wszystkie tamtejsze centra były w 1945 r. zniszczone i poddane zostały później zwykle problematycznej i zazwyczaj niepełnej odbudowie. Wszystkie wciąż funkcjonują. Dzieje się tak mimo różnorodnie objawiającej się cechy tych miejscowości - braku „kompletnych" historycznych śródmieść utraconych w trakcie wojny i jej następstw. A może to oznacza, że tradycyjne centra w małych miastach nie są już potrzebne?

\section{BIBLIOGRAFIA}

\section{Opracowania}

Adamczewska-Wejchert H., Wejchert K., Mate miasta, problemy urbanistyczne stale aktualne, Warszawa 1986.

Badania archeologiczne starych miast Warmii i Mazur a problemy ich rewaloryzacji. Materiaty z konferencji, Wykno 12-14 XI 1997, red. J. Wysocki, J. Michalski, Nidzica 1998.

Czernik Z., Architektura w obliczu wojennych zniszczeń. Odbudowa miast wschodniopruskich w PRL, [w:] Między forma a ideologia. Architektura XX wieku w Polsce, red. E. Perlińska-Kobierzycka, Warszawa 2012, s. 147-164.

Czubiel L., Domagała T., Zabytkowe ośrodki miejskie Warmii i Mazur, Olsztyn 1969.

Der Wiederaufbau Ostpreußens. Eine kulturelle, verwaltungstechnische und baukünstlerische Leistung, hrsg. von E. Göttgen. Königsberg 1928.

Domagała T., Miasta wschodniopruskie w okresie zimowej ofensywy Armii Czerwonej w 1945 roku, [w:] Odbudowa miast historycznych. Dokonania przesztości. Potrzeby i możliwości wspótczesne. Wyzwania przysztości, red. M. Lubocka-Hoffmann, Elbląg 1998, s. 40-54.

Domino J., Biskupiec, Dąbrówno, Kisielice, Mitomtyn, Susz, Zalewo. Szanse - brak szans, „Kurier Konserwatorski” 2010, nr 9, s. 22-28.

Dziedzictwo kulturowe Warmii-Mazur-Powiśla. Stan zachowania, potencjaty i problemy, red. J. Wysocki, Olsztyn 2006.

Lubocka-Hoffmann M., Miasta historyczne Zachodniej i Pótnocnej Polski. Zniszczenia i programy odbudowy, Bydgoszcz 2004.

Pawłowski K., Problemy nowej zabudowy w zabytkowych zespotach urbanistycznych Polski Pótnocnej, [w:] Zagadnienia ksztattowania nowej zabudowy mieszkaniowej i ustugowej w uktadach zabytkowych matych miast. Materiaty z konferencji TUP w Olsztynie, red. H. Adamczewska-Wejchert, Z. Jaczewski, Olsztyn 1971, s. 121-128.

Rzempołuch A., Architektura i urbanistyka Olsztyna 1353-1953, Olsztyn 2005. 
Rzempołuch A., Pieniężno, „Spotkania z Zabytkami” 1987, nr 4, s. 36-38.

Salm J., Idea Cittaslow a tożsamość miast województwa warminsko-mazurskiego. Między Umbriq a Warmia i Mazurami, [w:] Alternatywne modele rozwoju miast. Sieć miast Cittaslow, red. E. Strzelecka, Łódź 2017, s. 73-81.

Salm J., Miasta po trzykroć odbudowywane. Koleje losu historycznych ośrodków miejskich Polski Pótnocno-Wschodniej w 20. wieku, [w:] Tożsamość miasta odbudowanego. Autentyzm - integralność - kontynuacja. Materiaty międzynarodowej konferencji naukowej, Gdańsk, 10-11 maja 2001 roku, red. M. Cielątkowska, Gdańsk 2001, s. 107-112.

Salm J., Odbudowa miast wschodniopruskich po I wojnie światowej. Zagadnienia architektoniczno-urbanistyczne, Olsztyn 2006.

Salm J., Problematyka powojennej odbudowy i badań zespotu Starego Miasta w Pastęku, „Archeologia Historia Polona" 1996, t. 3: Materiaty z II Międzynarodowej Sesji Naukowej Uniwersyteckiego centrum Archeologii Średniowiecza i Nowożytności. Eódź 18-19 października1993 roku, s. 301-314.

Salm J., W poszukiwaniu zapomnianej tradycji. Nowa architektura w historycznych ośrodkach Polski Pótnocno-Wschodniej, [w:] Architektura wspótczesna w środowisku historycznym, red. R. Mikielewicz, Pasłęk 1995, s. 46-59.

Warmia i Mazury, t. 2, red. S. Zajchowska, M. Kiełczewska-Zaleska, Poznań 1953.

Zabytki urbanistyki i architektury w Polsce. Odbudowa i konserwacja, red. W. Zin, t. 1: Miasta historyczne, red. W. Kalinowski, Warszawa 1986.

\section{Jan Salm}

\section{WAR DAMAGE AS A FACTOR DETERMINING THE URBAN LANDSCAPE ON THE EXAMPLE OF THE TOWNS OF NORTH-EASTERN POLAND AND WHAT IS THE RESULT OF IT}

Summary. Wars have always had a significant impact on shaping the face of cities. It manifested itself through the evolution of fortifications, but also changes in urban and suburban buildings. The history of urban centers was obviously influenced by war damage, which led to a crisis, sometimes to the disappearance of an urban center. Sometimes, however, they were an impulse for slow or quick, planned or chaotic reconstruction depending on many factors. Removing the damage consisted in striving to restore the state from before the war, but usually it was also a pretext for planning reforms and corrections, which led to the deconstruction and blurring of the original system. Sometimes the reconstruction was not undertaken or limited only to selected buildings or fragments, and the suburbs took over the functions of the center. The specificity of these phenomena had (and still has!) A positive or negative impact not only on the perception of these centers, but also on their further development. The above-mentioned phenomena are well illustrated by cities located in North-Eastern Poland (Warmia-Masuria Province), i.e. in the former East Prussia. The cities of this historic land were mostly affected in the 20 th century by one, and in part by double war damage, and then by very heterogeneous forms of reconstruction. Parts of the cities were either not rebuilt at all or their historic centers 
were replaced with blocks of flats. In the former city centers, as a result of such actions, incoherent and disarmed complexes of buildings arose. The aim of the paper is to characterize these phenomena and try to compare them. It also raises the question of whether the traditional spatial arrangement of the historic city is needed by its contemporary inhabitants. There are three cities used as examples: Pasłęk, Pieniężno and Kisielice.

Keywords: War, damage, architecture, urban landscape, North-Eastern Poland, Prussia 